\title{
Characterizing Archaeological Assemblages from Eastern Lake Natron, Tanzania: Results of Fieldwork Conducted in the Area
}

\author{
Fidelis T. Masao
}

Published online: 12 February 2015

(C) The Author(s) 2015. This article is published with open access at Springerlink.com

\begin{abstract}
Unlike Peninj and Monik localities in western Lake Natron, eastern Lake Natron remains an archaeological terra incognita. A brief survey of the landforms adjacent to the eastern shoreline revealed 28 Stone Age archaeological sites exhibiting technological and typological features suggestive of the Acheulean Sangoan, Middle Stone Age (MSA), and Later Stone Age (LSA) distributed in three different landforms. While the majority of the assemblages were recovered from the surface, test excavations at two sites also yielded artifacts. The majority of the assemblages are MSA, predominantly made of chert and distributed on the landscape. Although intersite typological variability is negligible, the density of artifact concentration is variable, perhaps as a result of the factors of redeposition encouraged by topographic differentials.
\end{abstract}

Résumé Contrairement Peninj et localités Monik dans l'ouest du lac Natron, l'est du lac Natron reste une terra incognito archéologique. Un bref survol de l'reliefs adjacente à la rive est révélé 28 sites archéologiques de l'âge de pierre présentant des caractéristiques technologiques et typologiques évocateurs de l'Acheuléen Sangoan, Middle Stone (MSA) et plus tard Stone Age (LSA) répartis en trois reliefs différents. Bien que la majorité des assemblages ont été récupérés à partir de la surface, les fouilles d'essai à deux sites ont également donné des artefacts. La majorité des assemblages sont MSA principalement faits de chert et distribué sur le paysage. Alors que la variabilité typologique inter-sites est négligeable, la densité de concentration de l'artefact est variable, peut-être en raison des facteurs de re-dépôt encouragés par différentiels topographiques.

Keywords Eastern Lake Natron · MSA/LSA mixed industry · Chert

\footnotetext{
F. T. Masao $(\bowtie)$

College of Humanities, Department of Archaeology and Heritage, University of Dar es Salaam, P.O.Box 35050, Dar es Salaam, Tanzania

e-mail: fitman@udsm.ac.tz

F. T. Masao

e-mail: taliwawamasao@yahoo.com
} 


\section{Geological and Archaeological Background}

The Natron basin (Figs. 1, 2) is a half graben that forms a long chain of tectonic basins, considerably larger than the northern half of the greater basin, i.e., the Magadi sub-basin and Ewaso Ngiro River floodplain in southern Kenya. It is this river that provides most of the surface water to the lake. Both Lakes Natron and Magadi are situated on the rift floor of the Eastern Rift Valley System (Gregory Rift), bounded to the east and north by volcanoes, and escarpments to the west (Fig. 2). At times, Lakes Natron and Magadi were joined as one paleolake, Orolonga, but they are now separated after a shift that occurred around 9,000 BP (Baker 1958; Vanetti 2009/2010). The Shombole Volcano $(1,565 \mathrm{~m})$ separates the Magadi and Natron sub-basins while Oldonyo Sambu $(2,045 \mathrm{~m})$ was the barrier during the Lower Pleistocene (Luque et al. 2009). Massive outcrops of volcanoes aside, the salient geographical features here are the escarpments dominated by Nguruman, and extending from the northern basin into the west lake margin. The basin has a protracted history of volcanism, sedimentation, and faulting with the sedimentary deposits accumulating before about 2 million years ago (mya). They grade upward from the deltaic Humbu Formation to the lake deposits of the Monik Formation (Sherrod et al. 2013). Radiometric ages from these stratigraphic units suggest that Humbu and Monik Formations were deposited between 1.8 and 1.1 mya (Foster et al. 1997; Isaac and Curtis 1974; Manega 1993; Sherrod et al. 2013).

On the east, the Natron basin is punctuated by a network of horsts and grabens oriented north-south, a feature typical of the rift axis in Kenya and Tanzania (Baker

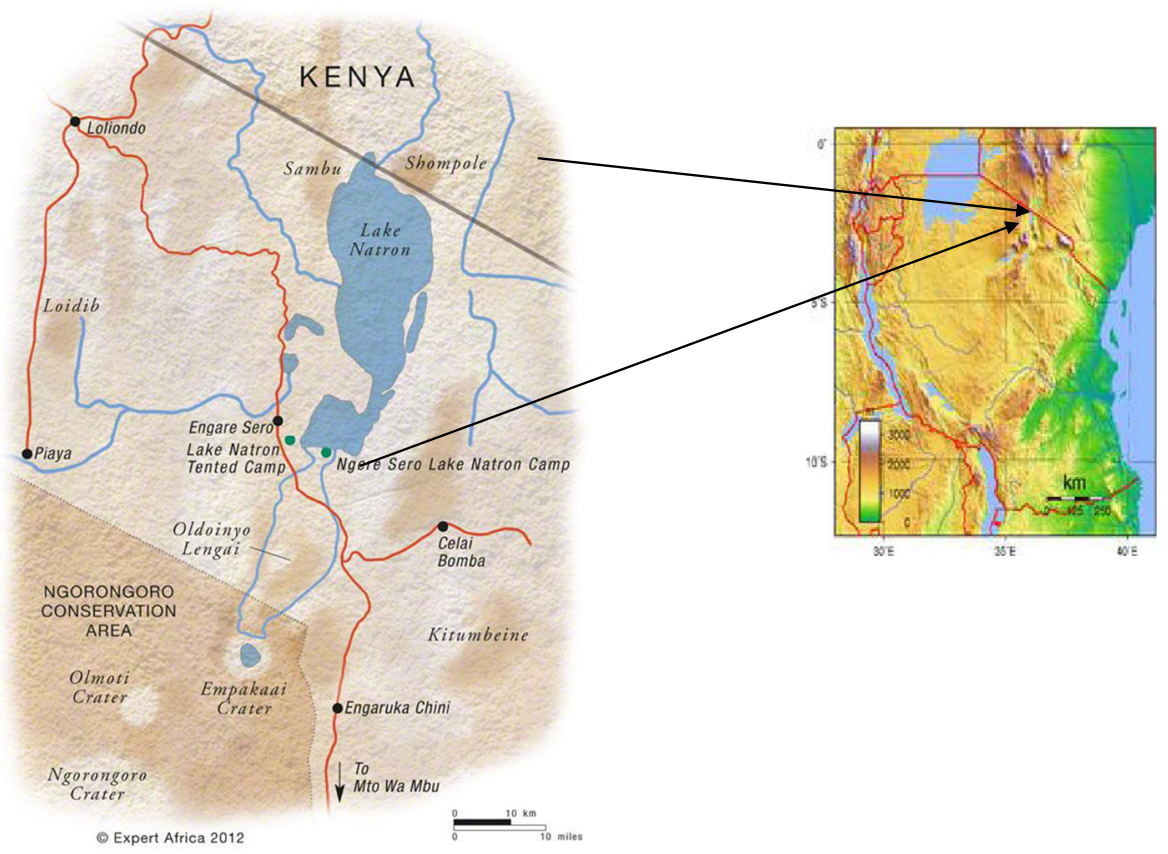

Fig. 1 Location of Lake Natron in northern Tanzania 


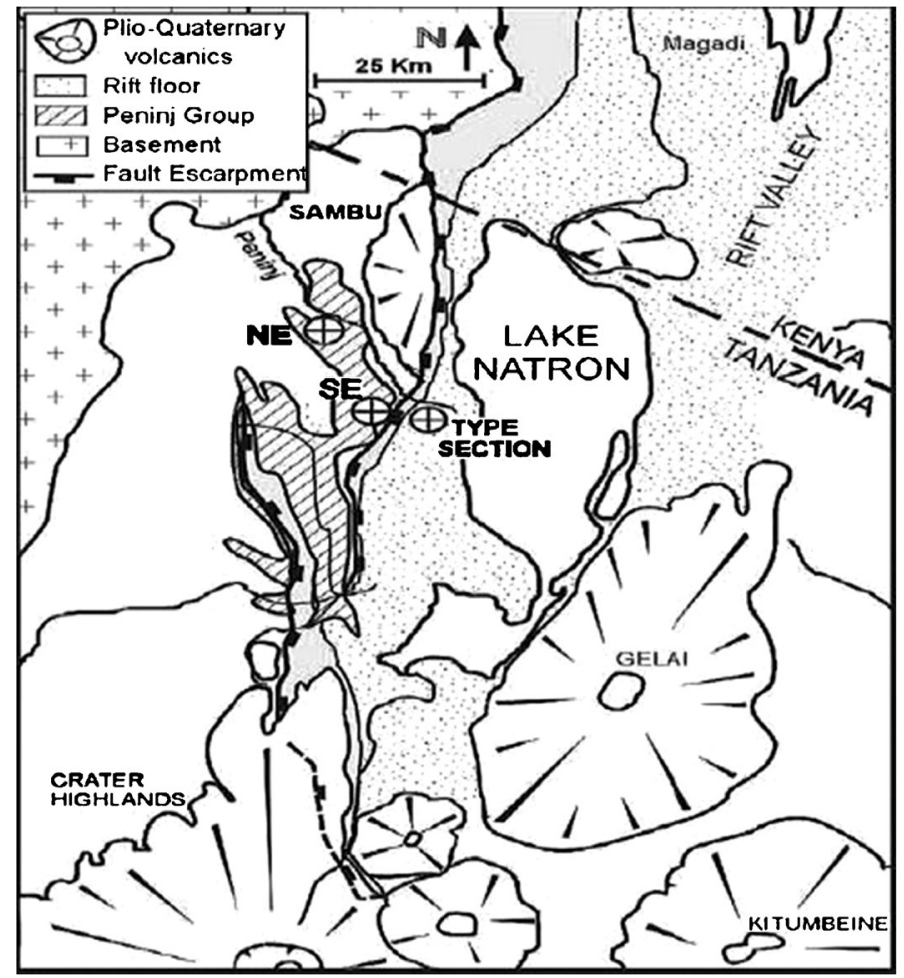

Fig. 2 Lake Natron and the local topography, after Mora et al. (2001)

1963, 1986), and the gradient is less steep and forms part of the Gelai hills. The slopes consist of Plio-Pleistocene sediments which are devoid of important fossils, unlike in the west, although they abound with artifacts.

In the south, the rift tectonics give rise to two parallel escarpments, the Sambu and Sanjan. The Sonjo Faults limit the basin to the west. South of Natron lies the Engaruka sedimentary basin separated from Natron by Oldonyo Lengai $(2,878 \mathrm{~m})$, an active carbonatite explosive volcano that erupted as recently as 2007/2008, the Kerimasi volcano, and a horst created by oblique faults (Luque et al. 2009; Sherrod et al. 2013) before rising to the Manyara escarpment (Fig. 2). On the southeast, the basin is bounded by the prominent Gelai shield volcano which rises gently from the shores of the lake to an altitude of $c a$. 2,940 $\mathrm{m}$ (Sherrod et al. 2013). Located to the west of Lake Natron is Peninj (Penin) (Fig. 2), best known for the australopithecine mandible that fits the famous Olduvai Zinjanthropus skull, Australopithecus boisei (Paranthropus boisei), as if they belonged to the same individual, and also for containing the earliest Acheulean sites contemporary to Konso Gardula sites in Ethiopia (Isaac and Curtis 1974; Schick and Toth 2006). The occurrences have been recorded at RHS-Mugulud and MHS-Bayasi sites in western Lake Natron.

Chert has formed from two sodium silicate minerals, magadiite $\left(\mathrm{NaSi}_{7} \mathrm{O}_{13}\right.$ $\left.(\mathrm{OH})_{3}-3 \mathrm{H}_{2}\right)$ and kenyaite $\left(\mathrm{NaSi}_{11} \mathrm{O}_{20} 5(\mathrm{OH})_{4}-3 \mathrm{H}_{2} \mathrm{O}\right)$ in the uppermost deposits 
of Lakes Natron and Magadi. The cherts, which consist of finely crystalline quartz, occur in massive bedded and nodular outcrops of irregular shape, with white coatings having reticulate surface patterns (Baker 1963; Hay 1968). These are the most abundant local sources for flaked stone artifact raw materials. Being saline and alkaline and hence rich in sodium bicarbonate, the lakes provide an environment which not only serves as a natural breeding ground for the lesser flamingo (Phoenicopterus minor) but also attracts industrial exploitation of the sodium bicarbonate deposits.

Palaeoanthropological work at Peninj was first initiated by R.E.F. Leakey and G.Ll. Isaac between 1963 and 1964 (Isaac 1967). From 1981 to 1983, an international team under the direction of Glyn Isaac investigated the area, but a hiatus followed, presumably due to Isaac's untimely death in 1985. In 1995, active though intermittent research resumed. However, apart from some references by Mturi (1976) and Toth and Schick (2006) to the Lake Natron sites, there is hardly a mention of the collection made by Isaac and his team. After 1995, a Spanish team resumed work in the Peninj area focusing on the Maritanane, MHS-Bayasi, and RHS-Mugulud areas (De la Torre et al. 2008; Dominguez-Rodrigo et al. 2001a, b, 2002). To date, a total of 27 palaeontological and 8 archaeological localities have been discovered. Most of the sites are located in the Humbu Formation, the lower member of the "Peninj Group" at the top of the Plio-Pleistocene stratigraphical sequence. Archaeological materials and fossil bones appear distributed unevenly in the three main areas around the modern Peninj River. Type section (Maritanane, Kamare, and Kipalagu), Southern Escarpment (Bayasi, Karonga North South and East Mugure), and Northern Escarpment (Mgudulu) are among the better known localities. While the foregoing concentrated on the Acheulean, Bushozi (2003) worked on the later industries of the Middle Stone Age (MSA) on the western escarpment of the lake.

The Humbu Formation is divided into two units: the Basal Sands and the Upper Sands with Clays. Research efforts have thus far concentrated in the Upper Sands with Clays as the Acheulean and Oldowan sites were found in this unit. Though still controversial, the unit is dated to between 1.6 and 1.5 mya (Isaac and Curtis 1974; Manega 1993; Thouveny and Taieb 1987). Normal magnetic stratigraphy suggests that it falls within the Olduvai subchron. The Acheulean and Oldowan sites are contemporary and co-occur in the Upper Sands with Clays of the Humbu Formation. The co-occurrence of the two industries is also known at Olduvai Bed II. For example, while the occurrence of the earliest Acheulean has been documented at the Olduvai site of EF-HR, a late Oldowan has been recognized at the stratigraphically contemporaneous MNK Skull site (De la Torre, personal communication, 2013; Leakey 1971). Like at Olduvai, most of the Acheulean sites are in fluviatile and proximal alluvial fan depositional environments, while the Oldowan ones are concentrated in a distal alluvial fan/lacustrine floodplain setting (Leakey 1971). Abundant fossil fauna is documented with the Oldowan sites near the lake, but bones are scarce in the Acheulean sites. From the cultural/archaeological point of view, the Lake Natron basin is best known from Peninj on the western side of the lake. To date, Lake 
Natron has yielded 17 australopithecine remains which include several teeth and an A. boisei mandible. The eastern part, however, is hardly known but could turn out to be an important archaeological landscape for the terminal Acheulean, MSA, and later occurrences as this report aims to emphasize.

\section{Methodology and Fieldwork}

The fieldwork was conceived as part of an investigation of the Environmental and Social Impact Assessment (ESIA) of the then-proposed Soda Ash Mining Project. The purpose was to avert or minimize destruction resulting from the project activities, as required by both the Tanzania National Environmental Management Council and The Antiquities Policy of the Ministry of Natural Resources and Tourism, as here quoted:

The Tanzania National Environmental Act 2004 and the Antiquities Policy of the Ministry of Natural Resources and Tourism 2008 require operations of all large projects which disturb the ground in any way, to be preceded by a thorough evaluation of the impact of the project to the cultural heritage and devise mitigation measures for which the costs should be borne by the respective project. As stated in Kiswahili, Utaratibu utakaohakikisha kuwa miradi yote mikubwa inayohusu uchimbaji au utubuaji wa ardhi unatanguliwa na tathmini za athari za miradi hiyo kwa malikale utawekwa bayana na gharama za kufanya tathmini hiyo zitakuwa ni sehemu ya mradi husika (2008, p. 17).

The archaeology team thus concentrated on the following:

1. Establishing the presence/location of archaeological sites and assessing the type and condition of cultural heritage in the area (eastern lake flats and area overlooking the lake flats)

2. Evaluation of uniqueness and scientific significance of the archaeological heritage

3. Collection of a sample of the archaeological heritage for study and description

4. Proposal of mitigation measures

With these objectives in mind, the team spent 10 days assessing the archaeological potential of the area and the immediate and remote threats that might be imposed by the proposed Soda Ash Project. Efforts at library research for information about the archaeology of the area to be impacted by the project proved futile, as there had been no previous archaeological investigation. Eastern Lake Natron was, until this study, a terra incognita archaeologically speaking, as echoed in Dominguez-Rodrigo et al.'s (2009a, b, p. 257) quotation:

Peninj could yield further surprises in the future. This book describes the archaeology of Lower Pleistocene but remains belonging to the MSA and LSA are far more abundant and appear scattered in thousands all over the 
landscape. Their lack of stratigraphic context, since they were deposited in the absence of sedimentary process (evidenced by several lithic bearing thick patina from exposure) is a handicap in their study. However, they remain to be properly studied and this should be considered in future research at Peninj.

Fieldwork proved to be much more fruitful. Artifact discovery and recovery were dominated by survey and a few test excavations opportunistically located over the landscape. Because it was pioneering work, survey was the best way to obtain a bird's-eye view of the archaeological and palaeontological heritage of the project area. Having established the area of impact as lying roughly between Lon/Lat $36^{\circ} 07^{\prime} 16^{\prime \prime}-36^{\circ} 8^{\prime} \quad 58^{\prime \prime} \mathrm{E}$ and $02^{\circ} 16^{\prime} 1^{\prime \prime}-02^{\circ} 20^{\prime} 0^{\prime \prime} \mathrm{S}$, an area $c a .10 \mathrm{~km}$ long, the team then walked it over, noting surface remains of artifacts and fossils and collecting samples in the process. Constraints such as time, difficult terrain, and differential archaeological visibility militated against employing more sophisticated sampling and surveying procedures, such as probabilistic sampling or stratified sampling. As long as there were no physiographical obstacles - steep-sided gullies or hills, or swampy grounds-survey methods consisted of the team of four people walking, spaced at 5-m intervals in the same direction. The team stopped whenever an archaeological surface was encountered. Several areas of unusual concentration of artifacts were observed (Fig. 3) in three different landforms, but only 28 were considered sites (Table 1) and sampled, while the majority were recorded for future followup, if needed.

The three landforms have been described as Lake Flats, Lake Terrace, and Ngejeki Plateau (Fig. 3).

Lake flats: These lie adjacent to the lake shore and as such they are liable to flood, especially during lake transgression or times of unusually heavy precipitation as in the last El Niño of 1998. They are devoid of vegetation, though isolated patches of grass may be encountered. The flats were littered with artifacts and chert nodules, the majority of which may have eroded down from the landforms upslope.

Lake terraces: Overlooking the lake flats, rising from the 630-m contour mark, are two rows of stepped narrow plains with a steep front. A feature of these landforms is the presence of gullies or korongos - some of which are deep and steep-running almost perpendicular to the eastern lake shore. Vegetation consists of sparse grass and occasional stunted bushes. The ground surfaces are littered with artifacts and unmodified cobbles of lava (phonolite), chert nodules, and a few obsidian chips.

Ngejeki Plateau: Upslope from the terraces and lying on the $c a$. 700-800-m contour mark is the landform which is almost uniformly flat and running in N-S orientation concordantly with the lake. Vegetation consists of grass and bush, the latter of which can become relatively thick and thus retard movement. The plateau is littered with artifacts of chert and cobbles of lava and quartzite as well as gravel. A few obsidian artifacts were also observed. 


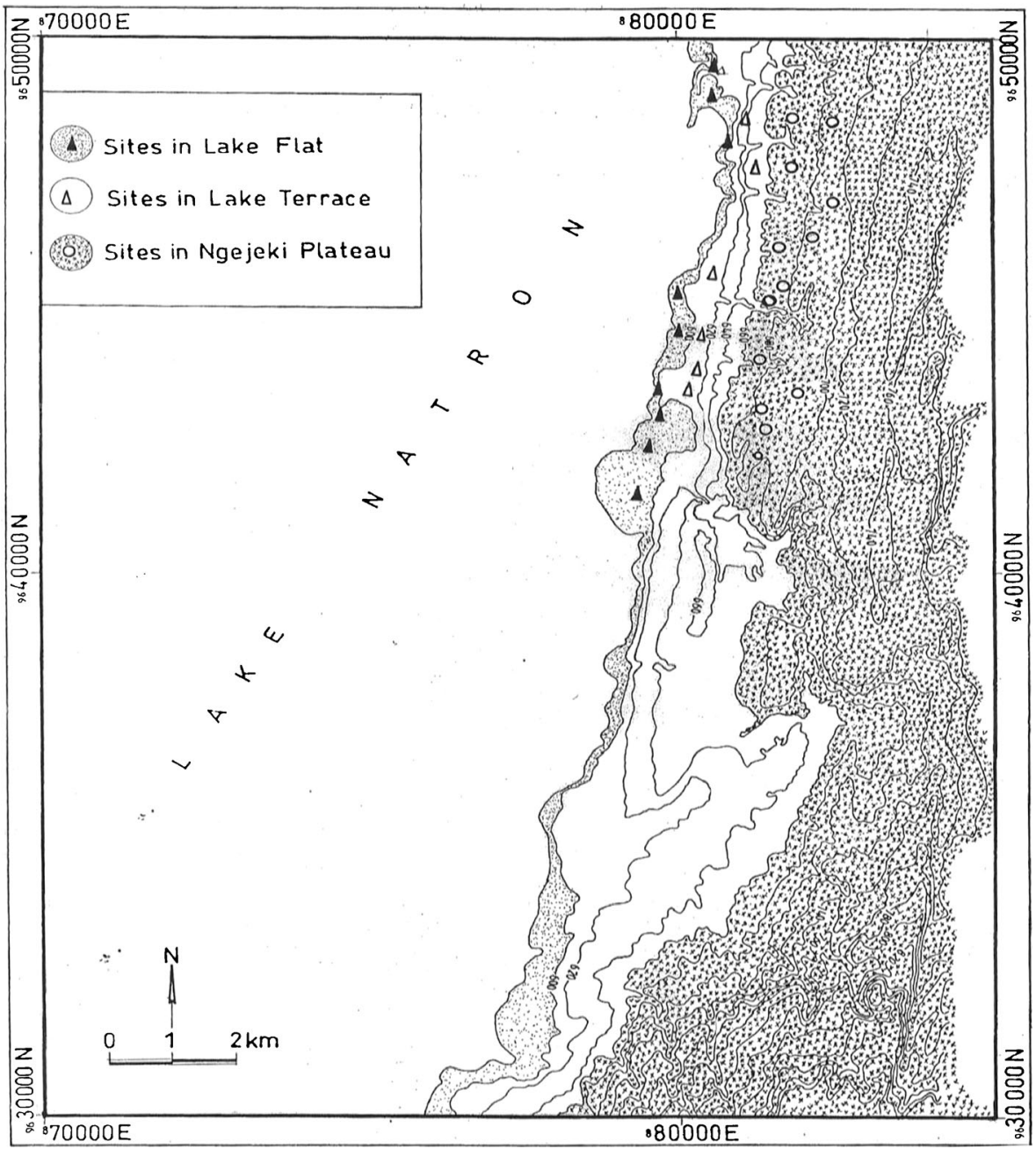

Fig. 3 Distribution of archaeological sites in the three landforms in eastern Lake Natron

As noted above, surveying and sampling were for the most part opportunistic, in the sense that only areas with good archaeological visibility, a dense scatter of artifacts, and easy accessibility were surveyed, while areas with formidable terrain were avoided. Nevertheless, the team felt it had covered a large enough area to be able to make scientifically valid statements about the archaeology of the study area. Figure 3 shows localities of dense concentration of artifacts.

The team began by surveying one of the korongos (gullies) known as Kipii $\left(36^{\circ} 07^{\prime} 30^{\prime \prime} \mathrm{E} / 2^{\circ} 20^{\prime} 0^{\prime \prime} \mathrm{S}\right)$ by the local people. The point was to gain a bird'seye view of the stratigraphy and temporal distribution of the archaeology, by examining the sides/banks of the korongo, which runs roughly SE-NW to the lake. At the time of the visit, it was flowing with a small amount of water but the river bed was strewn with rubble, the bulk of which was made up of chert 
Table 1 Coordinates of sites recorded and studied from the three landscapes

\begin{tabular}{|c|c|c|c|c|c|}
\hline \multirow{2}{*}{$\overline{F 1}$} & \multirow{2}{*}{$\begin{array}{l}\text { Lake Flats } \\
336^{\circ} 07^{\prime} 32^{\prime \prime} / 02^{\circ} 18^{\prime} 29^{\prime \prime}\end{array}$} & \multicolumn{2}{|c|}{ Lake Terrace } & \multicolumn{2}{|c|}{ Ngejeki Plateau } \\
\hline & & $\mathrm{T} 1$ & $36^{\circ} 08^{\prime} 26^{\prime \prime} / 02^{\circ} 16^{\prime} 4^{\prime \prime}$ & N 1 & $36^{\circ} 07^{\prime} 34^{\prime \prime} / 02^{\circ} 19^{\prime} 3^{\prime \prime}$ \\
\hline $\mathrm{F} 2$ & $36^{\circ} 07^{\prime} 54^{\prime \prime} / 02^{\circ} 16^{\prime} 59^{\prime \prime}$ & $\mathrm{T} 2$ & $36^{\circ} 08^{\prime} 21^{\prime \prime} / 02^{\circ} 16^{\prime} 4$ & N 2 & $36^{\circ} 07^{\prime} 36^{\prime \prime} / 02^{\circ} 18^{\prime} 57^{\prime \prime}$ \\
\hline $\mathrm{F} 3$ & $36^{\circ} 07^{\prime} 42^{\prime \prime} / 02^{\circ} 19^{\prime} 35^{\prime \prime}$ & $\mathrm{T} 3$ & $36^{\circ} 07^{\prime} 58^{\prime \prime} / 02^{\circ} 16^{\prime} 1^{\prime \prime}$ & N 3 & $36^{\circ} 07^{\prime} 36^{\prime \prime} / 02^{\circ} 18^{\prime} 57^{\prime \prime}$ \\
\hline $\mathrm{F} 4$ & $36^{\circ} 07^{\prime} 26^{\prime \prime} / 02^{\circ} 19^{\prime} 54^{\prime \prime}$ & $\mathrm{T} 4$ & $36^{\circ} 08^{\prime} 3^{\prime \prime} / 02^{\circ} 17^{\prime} 8^{\prime \prime}$ & N 4 & $36^{\circ} 07^{\prime} 52^{\prime \prime} / 02^{\circ} 18^{\prime} 32^{\prime \prime}$ \\
\hline F5 & $36^{\circ} 02^{\prime} 14^{\prime \prime} / 02^{\circ} 17^{\prime} 58^{\prime \prime}$ & T5 & $36^{\circ} 08^{\prime} 4^{\prime \prime} / 02^{\circ} 16^{\prime} 43^{\prime \prime}$ & N 5 & $36^{\circ} 07^{\prime} 54^{\prime \prime} / 02^{\circ} 18^{\prime} 28^{\prime \prime}$ \\
\hline F6 & $36^{\circ} 07^{\prime} 42^{\prime \prime} / 02^{\circ} 17^{\prime} 41^{\prime \prime}$ & T6 & $36^{\circ} 07^{\prime} 32^{\prime \prime} / 02^{\circ} 18^{\prime} 29^{\prime \prime}$ & N 6 & $36^{\circ} 08^{\prime} 8^{\prime \prime} / 02^{\circ} 18^{\prime} 17^{\prime \prime}$, \\
\hline F7 & $36^{\circ} 08^{\prime} 26^{\prime \prime} / 02^{\circ} 16^{\prime} 13^{\prime \prime}$ & & & N 7 & $36^{\circ} 08^{\prime} 42^{\prime \prime} / 02^{\circ} 17^{\prime} 35^{\prime \prime}$ \\
\hline \multirow[t]{6}{*}{ F8 } & $36^{\circ} 08^{\prime} 21^{\prime \prime} / 02^{\circ} 16^{\prime} 4^{\prime \prime}$ & & & N 8 & $36^{\circ} 08^{\prime} 58^{\prime \prime} / 02^{\circ} 17^{\prime} 8^{\prime \prime}$ \\
\hline & & & & N 9 & $36^{\circ} 08^{\prime} 26^{\prime \prime} / 02^{\circ} 16^{\prime} 13^{\prime \prime}$ \\
\hline & & & & N 10 & $36^{\circ} 0821 / 02^{\circ} 16^{\prime} 4^{\prime \prime}$ \\
\hline & & & & N 11 & $36^{\circ} 07^{\prime} 58 / 02^{\circ} 16^{\prime} 1^{\prime \prime}$ \\
\hline & & & & N 12 & $36^{\circ} 07^{\prime} 29^{\prime \prime} / 02^{\circ} 19^{\prime} 17^{\prime \prime}$ \\
\hline & & & & N 13 & $36^{\circ} 07^{\prime} 22^{\prime \prime} / 02^{\circ} 19^{\prime} 34^{\prime \prime}$ \\
\hline Total & 8 & & 6 & & 13 \\
\hline
\end{tabular}

nodules. On closer examination, some of the chert rubble in the korongo was found to be artifacts (Tables 2 and 3).

\section{Collection Techniques}

Time constraints allowed for only two approaches of sampling following survey-total recovery of exceptionally high concentrations of surface artifacts, and excavation of test pits. While surface scatters have limitations imposed by lack of vertical differentiation necessary for the separation of episodes of activity, they are nevertheless useful. The archaeological surface record has, in studies of land-use patterns, been recognized as an appropriate source of data independent of subsurface remains (Dunnel and Dancey 1983, cited by Camilli and Ebert 1992). It is further contended that the argument that postdepositional processes and disturbance render surface distributions of artifacts of little use for analysis becomes spurious, because almost all presently buried or surface material was originally surface (Lewarch and O'Brien 1983, cited by Camilli and Ebert 1992). While surface sampling assures recovery of a good sample size, test-pitting will assess the depth and temporal distribution of the archaeological heritage. These approaches were directed at two areas of high density of surface artifacts, one at $36^{\circ} 07^{\prime}$ $42^{\prime \prime} / 02^{\circ} 17^{\prime} 8^{\prime \prime}$ and the other at $36^{\circ} 07^{\prime} 26^{\prime \prime} / 02^{\circ} 19^{\prime} 54^{\prime \prime}$. The latter is an exceptionally extensive area, roughly $170 \times 150 \mathrm{~m}$.

To obtain a sample in the first locality, two approaches were employed:

1. A 5-m radius was inscribed in a spot at site F4 ( $\left.36^{\circ} 07^{\prime} 26^{\prime \prime} / 02^{\circ} 19^{\prime} 54^{\prime \prime}\right)$, opportunistically chosen, and all artifacts in the circle were collected. It was realized that the assemblages come from mixed contexts, being mostly surface, but recovery of the artifacts proceeded. A summary of the artifacts will be seen in Tables 1 and 2 below. 


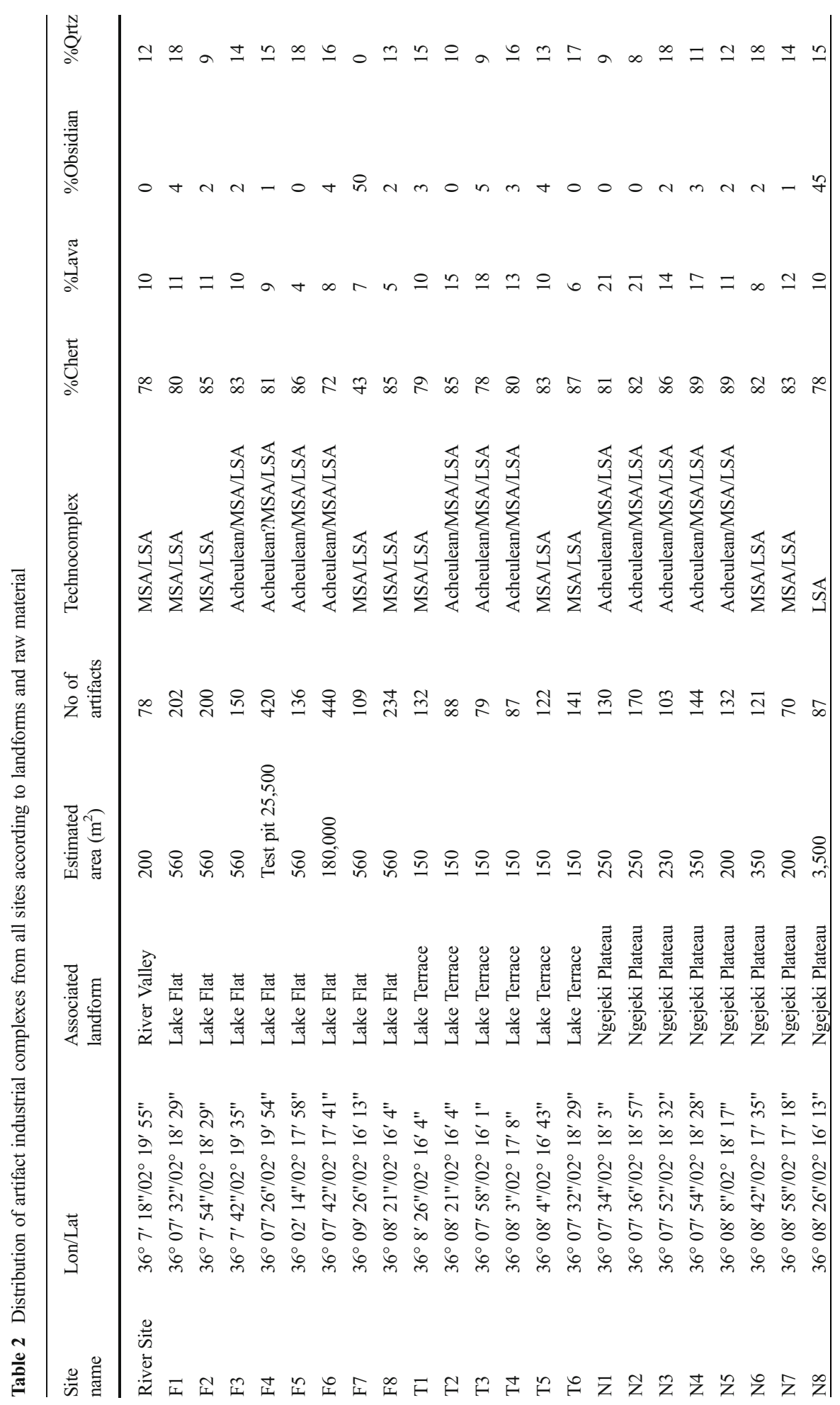




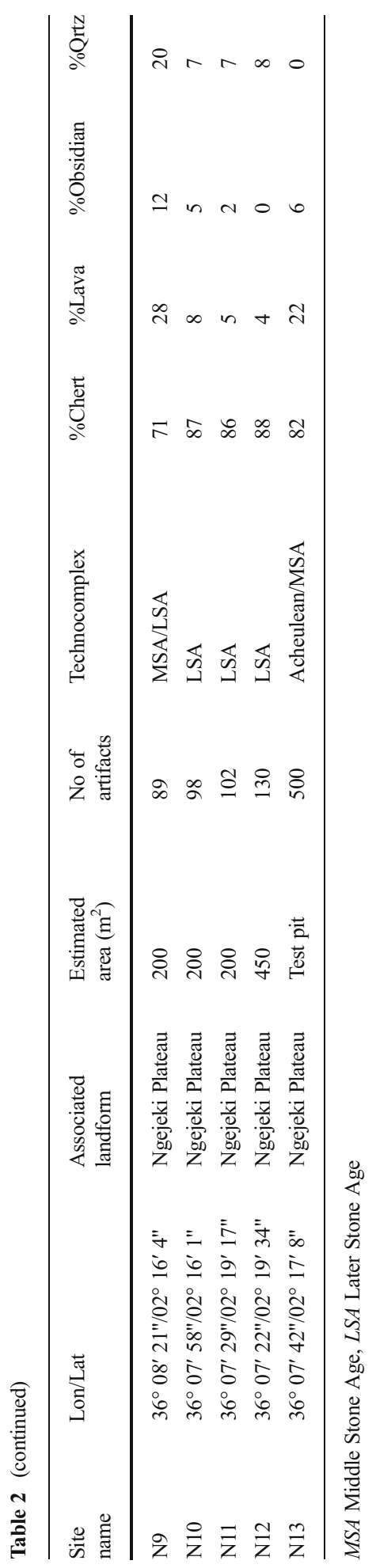


Table 3 Summary of artifacts recovered from the circle at locality $36^{\circ} 07^{\prime} 26^{\prime \prime} / 02^{\circ} 19^{\prime} 54^{\prime \prime}$ (site F4) according to types and raw material

\begin{tabular}{llllllll}
\hline Art type & Chert & Quartzite & Phonolite & Basalt & Obsidian & Total & Percentage \\
\hline Flake/blade & 80 & 3 & 5 & 0 & 8 & 96 & 21.38 \\
Ut. flake & 18 & 1 & 1 & 0 & 0 & 20 & 4.45 \\
End scraper & 8 & 2 & 2 & 0 & 2 & 14 & 3.12 \\
Side scraper & 13 & 3 & 0 & 0 & 2 & 18 & 4.01 \\
Core scraper & 13 & 0 & 0 & 0 & 0 & 13 & 2.90 \\
Notched piece & 1 & 0 & 0 & 0 & 0 & 1 & 0.22 \\
Backed piece & 2 & 0 & 1 & 0 & 0 & 3 & 0.67 \\
Crescent & 1 & 0 & 0 & 0 & 0 & 1 & 0.22 \\
Bifacial point & 10 & 0 & 0 & 0 & 0 & 10 & 2.23 \\
Bifacial pieces/misc & 18 & 2 & 3 & 0 & 0 & 23 & 5.12 \\
Unifacial point & 3 & 0 & 0 & 0 & 0 & 3 & 0.67 \\
Dimun bifaces & 7 & 0 & 0 & 0 & 0 & 7 & 1.56 \\
Unif core axe & 26 & 0 & 0 & 1 & 0 & 27 & 5.57 \\
Bif core axe & 41 & 0 & 0 & 0 & 0 & 41 & 9.13 \\
Multiplat core & 92 & 4 & 21 & 0 & 10 & 127 & 28.26 \\
Core/flk frag & 40 & 0 & 4 & 0 & 3 & 47 & 10.47 \\
Total & 373 & 15 & 37 & 1 & 25 & 451 & 99.98 \\
Percentage & 82.71 & 3.33 & 8.21 & 0.23 & 5.55 & 100 & \\
\hline
\end{tabular}

2. A $1 \times 4-\mathrm{m}$ stepped test pit was excavated to sterile as discussed below.

In addition, the team excavated three other test pits in the second area (Fig. 4), which provided a fairly good picture of the archaeological sequence of the area.

Test Pit 1: This was a $1 \times 4-\mathrm{m}$ Stepped Trench, Excavated at Site N 1 or $36^{\circ} 07^{\prime}$ $42^{\prime \prime} / 02^{\circ} 18^{\prime} 3^{\prime \prime}$

The excavation revealed four distinct stratigraphical units but with a lens between units 2 and 3e. Starting from the top, they are as follows:

1. A 15-cm-thick sandy clay with a few crude artifacts which, on the basis of the absence of a microlithic component coupled with MSA types, can be described as MSA.

2. A 22-cm-thick layer made up of sandy clay but with a concentration of rubble. Artifacts were noticeably rare, but were dominated by macrolithic double-edged scraper forms.

3. Compact silt/sand measuring $40 \mathrm{~cm}$ in thickness and very rich in artifacts made from phonolite and chert. Here the industry was definitely MSA as suggested by the employment of the Levallois technique, macrolithic double-edged scrapers, bifacial forms, discoidal cores, etc. While artifacts such as large double-edged scrapers, bifacial types, and discoidal cores still occurred, they were very scanty.

4. A 23-cm-thick layer of gravel and rubble with inclusions of decomposed bed rock. No artifacts were encountered here. Excavation was stopped at $100 \mathrm{~cm}$ below surface. 


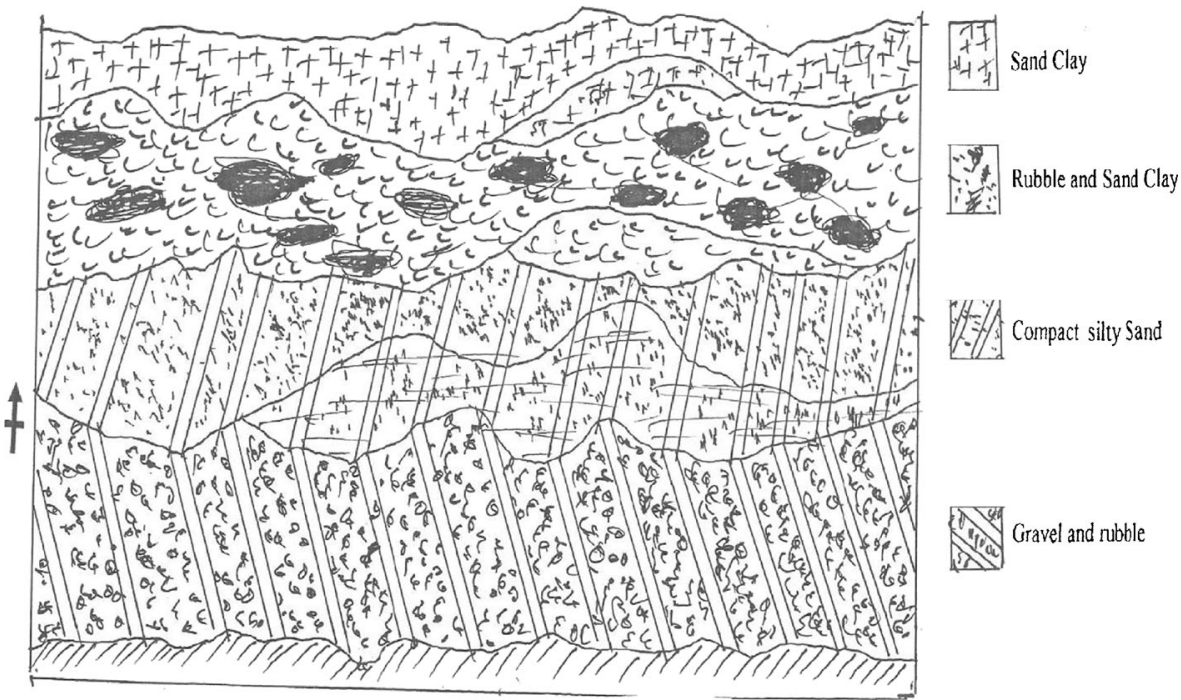

Fig. 4 Generalized stratigraphy as revealed by the northern bank of Kipii Korongo, scale 1:20

Test Pit 2: Site N 10 or Fossil Site $1,36^{\circ} 07^{\prime} 58^{\prime} / 02^{\circ} 16^{\prime} 1^{\prime \prime}$

A $50 \times 200-\mathrm{cm}$ stepped test pit was excavated at this locality to check the stratigraphy and vertical distribution of artifacts. A few MSA artifacts consisting of scraper forms, bipolar and discoidal core forms, and fossilized bones were found on the surface, and hence, the excavation anticipated finding a few more fossils. Only two stratigraphic layers were revealed.

1. The first layer measured $20 \mathrm{~cm}$ thick, and consisted of silt sand with very few artifacts of MSA affinity, such as scraper forms, blades, levallois flakes, and cores. No fossils were seen.

2. The second layer went from 20 to $50 \mathrm{~cm}$ below surface when artifacts stopped. Compact sandy clay which peels in layers yielded neither artifacts nor bones. The lithology turned into earthy clay with depth.

Test Pit 3 Lake Flat Site 1 (F1): $36^{\circ} 07^{\prime} 16^{\prime \prime} / 02^{\circ} 19^{\prime} 50^{\prime \prime}$

A $1.0 \times 1.5-\mathrm{m}$ test pit was excavated at this site. The surface was littered with artifacts and a few fossilized bones. The decision to excavate this site was influenced by the anticipation of finding more bones.

Three distinct stratigraphic units/levels were recognized:

1. A 14-cm-thick brown sandy clay with MSA artifacts dominated by the macrolithic double-sided scraper forms, blades, unmodified flakes, and an assortment of cores. This unit is distinguished from the underlying one by possessing a high density of flat chert nodules.

2. A 20-cm-thick layer of olive green waxy sandy clay with MSA artifacts though few. In addition to a bifacial disc or discoidal core of MSA or earlier industry, modified and unmodified flakes, double-sided scrapers, and 
an assortment of cores were also recovered. As in the other test pits, artifacts seem to decrease with depth.

3. A whitish laminated clay intercalated with waxy clay averaging $20 \mathrm{~cm}$ in thickness marked the bottom of the excavation. No artifacts were recovered and therefore further excavation was halted.

\section{Archaeological Findings:}

The survey has clearly established the presence of a large archaeological landscape in eastern Lake Natron, the short length of fieldwork notwithstanding (Fig. 3). The entire stretch from the lake flat up to the first terrace and onto the Ngejeki Plateau is one expansive archaeological landscape, but concentrations of artifacts vary from one locality to another depending on the relief. Localities on flat ground tended to have denser concentrations than those on slopes as mentioned above.

A variety of stone artifacts as summarized in Tables 3, 4, and 5 were recovered by surface survey/sampling and the excavations. A few of the artifacts are illustrated (Figs. 6, 7, 8, and 9). As discussed below, the recovered data suggest two distinct cultural industrial components, MSA and LSA, with the possibility of a late Acheulean component. The assemblage is reminiscent of comparable materials from the Lake Eyasi Basin and the western escarpment of Lake Natron (Bushozi 2003). Very few fossil remains were recovered, but this is possibly more a reflection of the recovery strategies than due to the absence of such relics. Conceivably, more and larger excavations might have yielded fossil remains.

\section{Research Results}

\section{Stratigraphy}

The section from the northern bank varies from 1.6 to $2.0 \mathrm{~m}$ in thickness and can be summarized from top to bottom as follows:

1. Top sandy clay ca. $30 \mathrm{~cm}$ thick with little rubble and few artifacts

2. Compact silty sand $c a .50 \mathrm{~cm}$ thick with very little rubble

3. Gravel and rubble ca. $60 \mathrm{~cm}$ thick with many chert nodules and artifacts

A more detailed section of the stratigraphy comes from the excavation (Fig. 4). In all the strata, no fossil bones were encountered. The team surveyed the floor of the river for about $200 \mathrm{~m}$ downstream and then moved to the northern side of the valley for about $500 \mathrm{~m}$ toward the lake. A transect of $c a .200 \mathrm{~m}$ wide was established on the northern side of the korongo between the Ngejeki ridge and the lake flats. Several patches of artifacts were observed in the areas where the top layer (soil) had been washed away. Such exposed surfaces were littered with chert nodules, basaltic rubble, and other rock types. One such concentration was seen at a locality denoted by the coordinates $36^{\circ} 07^{\prime} 18^{\prime \prime} / 2^{\circ} 19^{\prime} 55^{\prime \prime}$ where the whole surface, measuring more than $20 \mathrm{~m}$ on either side, was littered with chert artifacts. This concentration is referred to as River site. Most exposed patches exhibited comparable concentrations of artifacts and nonartifact chert pieces. 
Table 4 Summary of artifacts recovered from excavations at sites N1, N10, and F1 according to raw material

\begin{tabular}{|c|c|c|c|c|c|c|c|}
\hline Art type & Chert & Quartzite & Phonolite & Basalt & Obsidian & Total & Percentage \\
\hline Flake/blade & 51 & 1 & 70 & 8 & 13 & 143 & 28.60 \\
\hline Ut. Flake & 15 & 0 & 20 & 2 & 9 & 46 & 9.20 \\
\hline End scraper & 3 & 0 & 6 & 0 & 0 & 9 & 1.80 \\
\hline Side scraper & 9 & 0 & 9 & 1 & 0 & 19 & 3.80 \\
\hline Core scraper & 0 & 1 & 8 & 2 & 0 & 11 & 2.20 \\
\hline Notched pieces & 4 & 0 & 0 & 0 & 1 & 5 & 1.00 \\
\hline Backed pieces & 0 & 0 & 0 & 0 & 0 & 0 & 0.00 \\
\hline Crescent & 0 & 0 & 0 & 0 & 0 & 0 & 0.00 \\
\hline Bifacial Point & 0 & 0 & 0 & 0 & 0 & 0 & 0.00 \\
\hline Bifacial pieces/misc & 23 & 3 & 5 & 1 & 0 & 32 & 6.40 \\
\hline Unifacial point & 0 & 0 & 0 & 0 & 0 & 0 & 0.00 \\
\hline Dimin bifaces & 0 & 0 & 0 & 0 & 0 & 0 & 0.00 \\
\hline Unif core axes & 0 & 0 & 0 & 0 & 0 & 0 & 0.00 \\
\hline Bif core axes & 0 & 0 & 0 & 0 & 0 & 0 & 0.00 \\
\hline Multiplat core & 52 & 2 & 23 & 9 & 6 & 92 & 18.40 \\
\hline Singleplat core & 4 & 0 & 12 & 0 & 0 & 16 & 3.20 \\
\hline Bipolar core & 1 & 0 & 9 & 0 & 2 & 12 & 2.40 \\
\hline Core/flk frag & 30 & 0 & 70 & 0 & 15 & 115 & 23.00 \\
\hline Total & 192 & 7 & 232 & 23 & 46 & 500 & 100 \\
\hline Percentage & 38.4 & 1.4 & 46.4 & 4.6 & 9.2 & 100 & 100 \\
\hline
\end{tabular}

\section{Artifacts}

Cursory examination of the artifacts revealed an Acheulean-like biface made from basalt (the only artifact from this material), a diminutive biface or bifacial point, scrapers, notched pieces, and several flakes and cores. This observation was important because it indicates the type of archaeology to expect from future research. The team also noted variable concentrations at 26 localities in addition to the river floodplain site, 8 in the lake flat, 6 in the lake terrace overlooking the lake flat, and 12 in the Ngejeki plateau, herein referred to as F1-8 for lake flats, T1-6 for lake terrace, and N1-12 for the Ngejeki sites (Table 1.).

The Lake Flats Sites Areas liable to have come under the influence of lake transgression were observed to have several sites of varying artifact types and concentration. Altogether, eight sites, as shown in the table of sites below, were recorded from this landscape and studied. Finds from the sites were dominated by MSA (Table 4), although there were a few other types: e.g., bifaces that belong to the Acheulean and Sangoan on the one hand, and LSA implements on the other. The latter are represented by some types, especially scrapers (thumb nail and convex) and detached pieces, whose overall size (less than $5 \mathrm{~cm}$ in overall dimension) is considered microlithic and hence LSA. Unfortunately, no ostrich egg shell beads were encountered. Artifacts were predominantly made from chert. Their state of preservation varied from near fresh, to 
Table 5 Summary of artifacts recovered from excavations according to raw material

\begin{tabular}{llllllll}
\hline Art type & Chert & Quartzite & Phonolite & Basalt & Obsidian & Total & Percentage \\
\hline Flake/blade & 51 & 1 & 70 & 8 & 13 & 143 & 28.60 \\
Ut. Flake & 15 & 0 & 20 & 2 & 9 & 46 & 9.20 \\
End scraper & 3 & 0 & 6 & 0 & 0 & 9 & 1.80 \\
Side scraper & 9 & 0 & 9 & 1 & 0 & 19 & 3.80 \\
Core scraper & 0 & 1 & 8 & 2 & 0 & 11 & 2.20 \\
Notched pieces & 4 & 0 & 0 & 0 & 1 & 5 & 1.00 \\
Backed pieces & 0 & 0 & 0 & 0 & 0 & 0 & 0.00 \\
Crescent & 0 & 0 & 0 & 0 & 0 & 0 & 0.00 \\
Bifacial Point & 0 & 0 & 0 & 0 & 0 & 0 & 0.00 \\
Bifacial pieces/Misc & 23 & 3 & 5 & 1 & 0 & 32 & 6.40 \\
Unifacial point & 0 & 0 & 0 & 0 & 0 & 0 & 0.00 \\
Dimin bifaces & 0 & 0 & 0 & 0 & 0 & 0 & 0.00 \\
Unif core axes & 0 & 0 & 0 & 0 & 0 & 0 & 0.00 \\
Bif core axes & 0 & 0 & 0 & 0 & 0 & 0 & 0.00 \\
Multiplat core & 52 & 2 & 23 & 9 & 6 & 92 & 18.40 \\
Singleplat core & 4 & 0 & 12 & 0 & 0 & 16 & 3.20 \\
Bipolar core & 1 & 0 & 9 & 0 & 2 & 12 & 2.40 \\
Core//flk frag & 30 & 0 & 70 & 0 & 15 & 115 & 23.00 \\
Total & 192 & 7 & 232 & 23 & 46 & 500 & 100 \\
Percentage & 38.4 & 1.4 & 46.4 & 4.6 & 9.2 & 100 & 100 \\
\hline & & & & & & & \\
\hline
\end{tabular}

slightly rolled, to patinated. Distributional densities varied from site to site, but the average was calculated as being five artifacts per square meter, while areas of concentration or sites varied from 280 to $320 \mathrm{~m}^{2}$, i.e., $300 \mathrm{~m}^{2}$ on average. At site F6 $\left(36^{\circ} 07^{\prime}\right.$ $\left.42^{\prime \prime} / 02^{\circ} 17^{\prime} 41 "\right)$, a very expansive area on the lake flats measuring $400 \times 450 \mathrm{~m}$ with a rich scatter of both rubble and artifacts was observed. Although quartzite occurs in great quantity, chert still dominates. It is one of the more important collections, because of the presence of bifaces including hand axes and core axes which are considered to be the fossiles directeurs of the Acheulean and Sangoan, respectively.

The Lake Terrace The first five sites as shown in the table of sites occur in the upper lake terrace, while the last one on the list, at $36^{\circ} 07^{\prime} 32^{\prime \prime} / 02^{\circ} 18^{\prime} 29^{\prime \prime}$, is associated with the lower terrace. Unlike the lake flats, the terraces are made up of slopes with gradients of $25 \%$ on average, punctuated by steps whose width is variable but hardly exceeds $10 \mathrm{~m}$. At locality $36^{\circ} 07^{\prime} 32^{\prime \prime} / 02^{\circ} 18^{\prime} 29^{\prime \prime}$ in the lower terrace, a concentration of artifacts and a few fossils was encountered. Due to the fossil remains, the locality was earmarked for excavation. On average, the scatter of artifacts at this locality covered an area of $200 \mathrm{~m}^{2}$ in all cases, though density varied intersite and intrasite. Artifacts were found in differing densities of concentration and distribution. As with the lake flats, the majority of the artifacts are made from chert. The assemblage is dominated by variously bifacially trimmed implements, diminutive hand axes, discoids, and a variety of scraper forms in addition to microlithic types, thus suggesting a mixture of MSA and an even earlier industry, the Acheulean with 
LSA. There is no significant difference in either implement types or frequencies between the lake flats and the terraces, but a few more implements made from lava and quartzite were encountered. There are no features to suggest that the artifacts have rolled down from the Ngejeki plateau although the possibility cannot be ruled out.

Some of the chert artifacts are patinated while those made from other raw materials were rather heavily weathered, suggesting that unlike at the previous site, the artifacts have been exposed for a long(er) time. There were no other artifact clusters of interest in the upper or lower terrace.

Ngejeki Paleau Sites Eleven localities as shown on the table of sites (Tables 1 and 4), covering an average surface area of $250 \mathrm{~m}^{2}$ each, were recorded and sampled. Recognized types included crude picks and a biface, both of which are made from quartzite, and Levalloisian flakes made from chert. There were several other artifacts, all of which suggest MSA affinity on typological grounds. However, at one of the sites, $36^{\circ} 08^{\prime} 26^{\prime \prime} / 02^{\circ} 16^{\prime} 13^{\prime \prime}$, a high concentration of obsidian and a few chert LSA microlithic artifacts were encountered. Two more sites, $36^{\circ} 07^{\prime} 29^{\prime \prime} / 02^{\circ} 19^{\prime} 17^{\prime \prime}$ and $36^{\circ} 07^{\prime} 22^{\prime \prime} / 02^{\circ} 19^{\prime} 34^{\prime \prime}$ close to the team's camp on the plateau, exhibit a rich scatter of chert artifacts. The assorted assemblages are dominated by cores, presumably because they are more resistant to slope wash than the lighter artifacts. Some of the flakes had denticulate edges which, for some, could have resulted from use, but others are definitely significant or deliberate types. As summarized in Tables 2 and 3, the archaeology from most of the localities is more or less comparable, at least in terms of types and raw material regardless of the associated landforms.

\section{Technical Attributes of the Assemblages}

It should be pointed out that the assemblages described below have been recovered from both surface contexts as well as excavations. They are typologically and technologically comparable, and hence, the surface material can be assumed to be representative of the rather shallow stratified record, although the surface survey yielded more material.

Flakes and Blades (Detached Pieces) Judging by the presence of dorsal flake scars, the majority seems to have been struck from prepared cores, but a few exhibit cortex and point platforms, indicating that they were struck from unprepared cores. Most of the flakes display at least two negative scars on the dorsal side and range from 7 to $12 \mathrm{~cm}$ and $1.5-5 \mathrm{~cm}$ in length and width, respectively. The breadth/length ratios show that at least $25 \%$ of the flakes would be considered blades. McBrearty (1988) has pointed out that gross dimensions such as length are a direct reflection of the core size and as such, of the constraints imposed by the raw material, while the degree of flake elongation expressed by the $\mathrm{B} / \mathrm{L}$ ratio is an indication of flaking technique, a cultural factor. Based on experiments conducted by the author, flakes and blades could be described technically as knives, the most convenient implements to perform cutting due to their sharp edges. Compared to other unmodified artifacts, the author would be inclined to put flakes and blades into the utilizable artifacts category as utilized flakes. 
Utilized Flakes As already remarked, flakes are perhaps the most efficient implements for all functions involving cutting. A total of 20 and 46 flakes representing 4.45 and $9.2 \%$, recovered from the surface and excavations, respectively, exhibited some edge damage which could have resulted from use. Because most of the flakes had been lying on the surface for an indeterminate time, it is conceivable that part of the edge damage is postdepositional.

Scrapers The scrapers are dominated by the end and side types which account for 7.12 and $4.6 \%$ of the surface and excavated assemblages, respectively, and as such they form the largest formal tool category. In some, the trimming to produce the scraper edge is located on both sides as well as an end, but such pieces are scored as either side or end depending on where the trimming is more prominent. A few of the scrapers are irregular or core scrapers.

Points A variety of artifacts that have been trimmed both lightly and intensively on both sides were recovered. These are implements which have attained their shape as a result of deliberate trimming as opposed to technical types which, though of the same shape, lack trimming. Some of these fall into bifacial points on account of exhibiting trimming on both sides and tapering into a point, as opposed to other bifacial forms such as diminutives hand axes. On average, they were rare, accounting for only $2.23 \%$ of the surface assemblage out of 450 artifacts.

Miscellaneous Bifacial Pieces These are intensively or lightly trimmed on both sides, but since they do not conform to any discernable form in statistically significant numbers, they have been referred to as miscellaneous bifacial pieces. They may be ovate, cordiform, triangular, or trapezoidal in form. Invariably, they are made from chert nodules which still bear patinated cortex. They account for between 5 and $6.4 \%$ of the surface and stratified assemblages, respectively.

Bifaces (Hand Axes) Seven bifaces (1.56 \%) were recovered from the surface collection. These have been described as diminutive hand axes due to their relatively small size. They range from 10 to $14 \mathrm{~cm}$ in length and 6-9 $\mathrm{cm}$ in breadth. On average, they are intensely worked on both sides, although some patinated cortex can be seen on two of them.

Core Axes Of the surface assemblage, $41(9.13 \%)$ and 25 (5.57\%) implements were recognized as bifacial and unifacial core axes, respectively. As the name suggests, the former are worked on both sides, while the latter are trimmed on one side only. In both, the trimming is restricted to one end (distal), leaving the rest of the artifact, including the butt, unworked. Core axes are of special interest, because together, with crudely made picks and knives, they are considered the fossiles directeurs of the Sangoan, an MSA variant that is supposedly a woodworking adaptation. Their absence from the Eyasi sample has therefore led Mehlmann (1989) to consider the 1977/1981 sample from Eyasi not to be Sangoan, although these attributes, contrary to Mehlmans's attribution, are also reported in the Eyasi Westbucht and Nordostbucht collection presently stored at the Universitat Tubingen (Rafalski et al. 1978, pp. 175-76). To 
describe the Eyasi collection, Mehlmann (1989) has introduced the term Njarasa Industry after the name of a local hill. The Natron core axes are distinguished from hand axes not only by the untrimmed butts but also by their low flake scar counts, thick cross section, and blunt or chisel-shaped ends as opposed to the more rounded/pointed ones in the case of hand axes (Clark 1975: 317, Mehlmann 1989: 160). Both the bifacial and unifacial core axes are comparable in length and breadth, with a mean length and breadth of 9 and $5 \mathrm{~cm}$, respectively.

Cores This is the most dominant category, accounting for over $52 \%$ of the assemblage, the majority being surface finds. The exceptionally higher proportion must be attributed to a number of factors including differential sorting, whereby the lighter artifacts have more easily succumbed to hydrological slope wash, while the formal and cutting implements are more likely to be carried away from the spot of manufacture. They have been divided into multiplatform or polyhedral (46.6\%), bipolar $(2.4 \%)$, and single platform (3.2\%). Discoidal cores which are indicative of MSA were not observed, but this may simply be a reflection of differential sorting especially with the surface material. No attempt has been made to divide the polyhedral cores further in this report, but it was observed that some are Levallois while others are cylindrical. The latter would imply detachment of blades as opposed to ordinary flakes. On examining the cores in this assemblage, most have means whose greatest dimension is $15 \mathrm{~cm}$, an observation which seems to corroborate McBreaty's (1988) observation.

Core/Flake Fragments These are probably shatter which resulted from tool manufacture. They are recognized from natural shatter by the degree of angularity. The fact that they are found in such high density $(10.47 \%)$ may suggest that the surface assemblage has not been very much disturbed, although one would expect a higher proportion than that recorded for cores.

Raw Material Tables 4 and 5 and Fig. 5 clearly show that chert is by far the predominant material used in these assemblages, accounting for more than $82 \%$ of all the materials. Chert's popularity is attributed to its superior fracturing. The dominance has also been recorded west of the lake where its occurrence exceeds all other materials used during MSA (Bushozi 2003). Other raw materials include phonolite, obsidian, quartzite, and basalt.

\section{Discussion}

In reporting new discoveries of stone archaeological assemblages, one is always tempted to discuss them under the rubric of the classic Early, Midde, and Late Stone Ages used in sub-Saharan Africa. However, there are many problems which can arise from the use of these terms. For example, artifacts are often assigned to the MSA on purely typological or technological grounds; the MSA is thought of as a chronostratigraphic unit though very inadequately defined. This might lead to eschewing the crucial first steps of establishing context and defining local sequences. Poorly 


\section{Percentage}

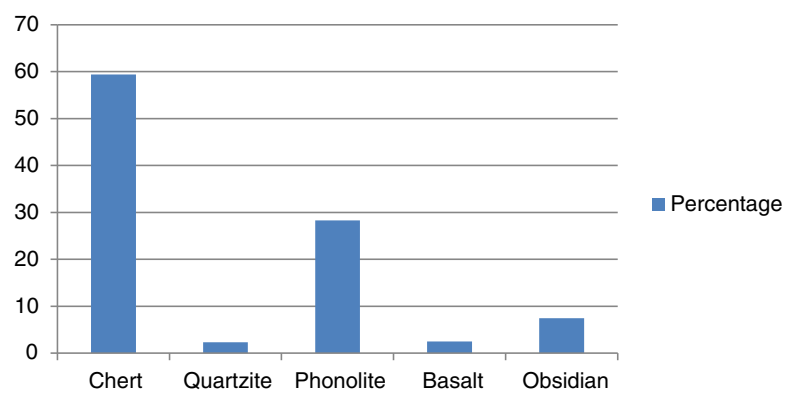

Fig. 5 Percentage distribution of artifact raw material from site F4 (surface) and sites N1, N10, and F1 (excavation) combined

documented or inadequately described assemblages find their way into the category MSA without adding anything to our understanding. Second, the use of the term Middle Stone Age suggests that the age of the material is known, while in most cases, it is not (McBrearty 1988). Aware of these problems, recent investigators have started focusing on detailed studies of regional "MSA" assemblages especially in Southern Africa, Tanzania, and Kenya. To this end, they have proposed local names describing the industries (McBrearty 1988, 1992; Mehlmann 1979, 1989). With this in mind, the discussions that follow and the conclusions arrived at must be understood as tentative, pending further investigation in the area.

The MSA is taken to be the cultural expression of anatomically modern humans, a period that lasted from 200,000 to 20,000 years BP, which marked the beginning of regional variation in technology and cultural adaptation (Willoughby 1993). In eastern Africa, assemblages postdating 49,000 BP would not be typical MSA (Gliganic et al. 2012).

Compared to earlier and later industries, the MSA is still relatively unknown in Tanzania. Barely over two decades ago, it was only in South Africa that the MSA wason the basis of the sequence from the type section at Klasies River and other sites-well known. Four MSA stages have been recognized-MSA I to MSA IV — with a distinct microlithic Mode 5 industry sandwiched in the middle (Willoughby 2007). In Kenya, the MSA became a focus in the 1960s and 1970s as witnessed by the work of Barbara Anthony (1978), Sally McBrearty (1981), and Harry Merrick (1975) as thoroughly reviewed by Clark (1988). The 1990s witnessed more vigorous efforts directed at MSA/LSA, and sites in Koobi Fora, Karari escarpment, Kapthurin Formation, Mukogodo Hill in the Laikipia Plateau in North Kenya, and Tol and Kipsing River Valley were excavated and studied. However, the most intensive studies have been directed at both MSA and LSA sites in the Rift Valley and the Lake Victoria Basin. Sites such as Enkapune ya Muto, Prospect Farm, Prolonged Drift, Lukenya Hill, Songhor, Simbi, and Muguruk are now well known to African prehistorians. In many of these sites, the MSA/LSA transition may have occurred before 46,000 years ago (Ambrose 1998; Kusimba and Kusimba 2003; McBrearty 1981, 1991, 1992, 1993, 1999; Skinner et al. 2003; Willoughby 2007). Tanzania, on the other hand, has lagged behind. Willoughby (2007, p. 260) has noted in particular that most of the MSA-related research has been in the north, with little study of the rest of the country. 
However, the last decade has witnessed expansion of the MSA and MSA/LSA to southern and southeastern Tanzania. As far back as 1970, Clark (1970) had surveyed the Songwe River and reported MSA deposits from the lower sediments of its branch, the Nyara River. A second survey in the same region by McBrearty et al. $(1982,1984)$ located MSA materials in both stratigraphic contexts and on the surface of the flood plain. Recently, Harvey (1993) has carried out further fieldwork in the area and discovered 17 MSA and MSA/LSA sites while Bushozi (2011; Bittner et al. 2007), working northeast of the area in Iringa, has also reported MSA and MSA/LSA deposits at Magubike and Mlambalasi Rock shelters.

The chronology of the MSA in Tanzania is not yet well resolved. A number of scholars have recognized and adequately described long cultural sequences. These include Mehlmann (1989) in the Lake Eyasi Basin and southern Serengeti in Tanzania, particularly at the Skull site, Mumba Hole, and Nasera, which provided chronometric dating; and Gliganic et al.'s work (2012), at three typical MSA sites (Njarasan, Sanzako, Kisele), two MSA/LSA sites (Mumba, Naseran), and three sites with fully developed LSA industries (Lemuta, Silale, and Olmoti). The industries are
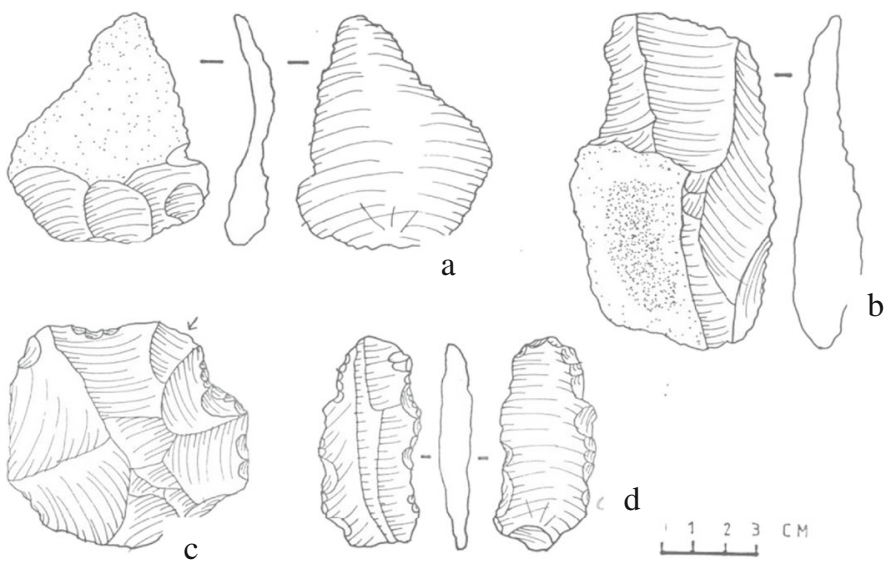

d
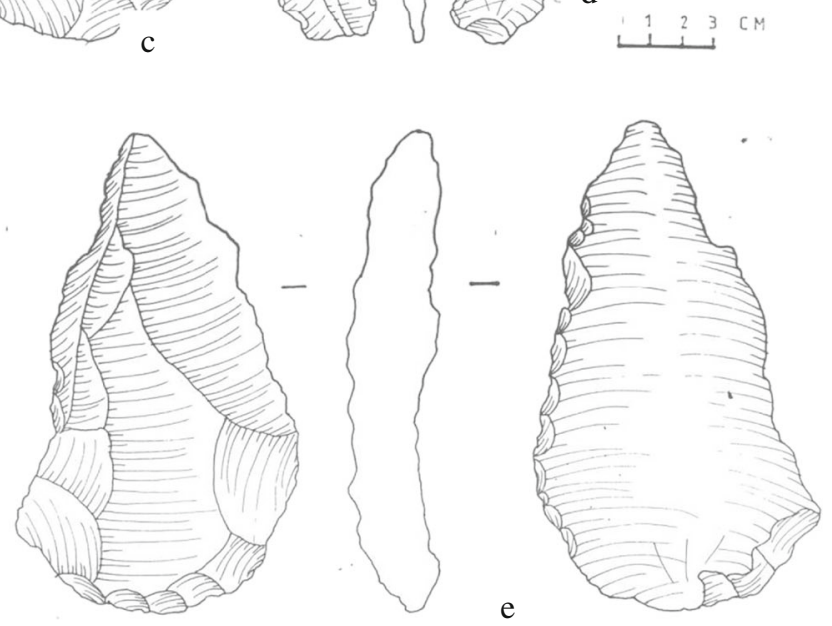

Fig. 6 a Retouched flake (site F1), b Levallois flake (site N1), c disc (site N10), d side scraper (site F3), and e Levallois blade (site N2) 
named after local geophysical features in the Serengeti and Lake Eyasi Basin. In the latter, previous uranium-series dating has produced dates of 131,000 years ago for the Sanzako, while the Kisele industry was estimated to be 90,000 BP, but recent dating attempts using multiple approaches including optically stimulated luminescence (OSL) and infrared stimulate luminescence (IRSL) have provided dates for the deposits associated with latest MSA Kisele Industry, and the earliest MSA/LSA Mumba Industry ranging from $63.4 \pm 5.7$ to $56.9 \pm 4.8 \mathrm{ka}$ (Gliganic et al. 2012; Mabulla 1996). An age of $49 \pm 4.3 \mathrm{ka}$ has been obtained for the latest Mumba Industry containing ostrich eggshell beads (Gliganic et al. 2012). The only other Tanzanian well-documented MSA/ LSA industries reported in the literature come from the Serengeti open-air site of Loyangalani, the Ndutu and Nasiusiu Beds at Olduvai, and Kisese rock shelter in central Tanzania (Bower and Mabulla 2008, p. 54; Bower et al. 1985; Leakey et al. 1972; Mabulla 1996; Masao 2008; Skinner et al. 2003). The Loyangalani site has produced both MSA and LSA, where the MSA includes many scrapers, borers, few points or bifaces, and disc and Levallois cores (Bower and Mabulla 2008, p. 54).

Attempts to look for ostrich eggshell beads in eastern Natron ended in futility. At the Loyangalani site, ostrich egg shell beads which were previously reported to have dated to 70,000 BP and inferentially associated with the MSA and taken as evidence of symbolic behavior are now questioned. Not only has this date been disputed but it has now been demonstrated that the beads belong to the LSA on the basis of amino acid racimization dating, and the earlier data have now been retracted, although they has yet to be published. More concrete evidence of the association of the MSA with the
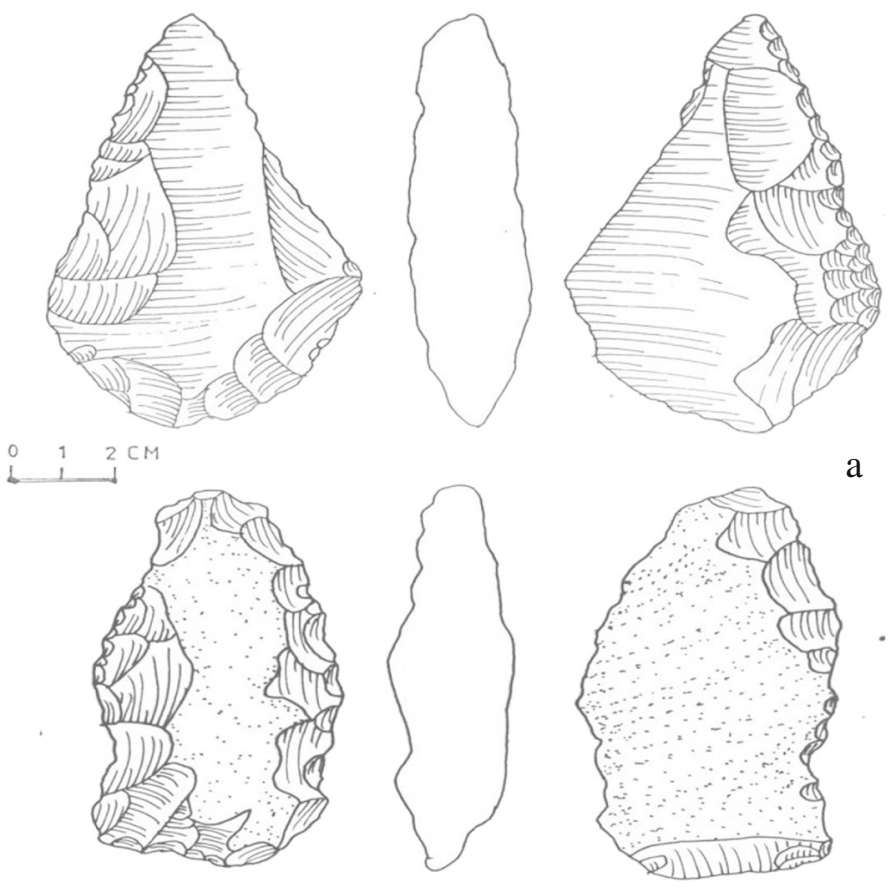

b

Fig. 7 a Unifacial point with a scraping edge (site T4). b Side end scraper (site F5) 


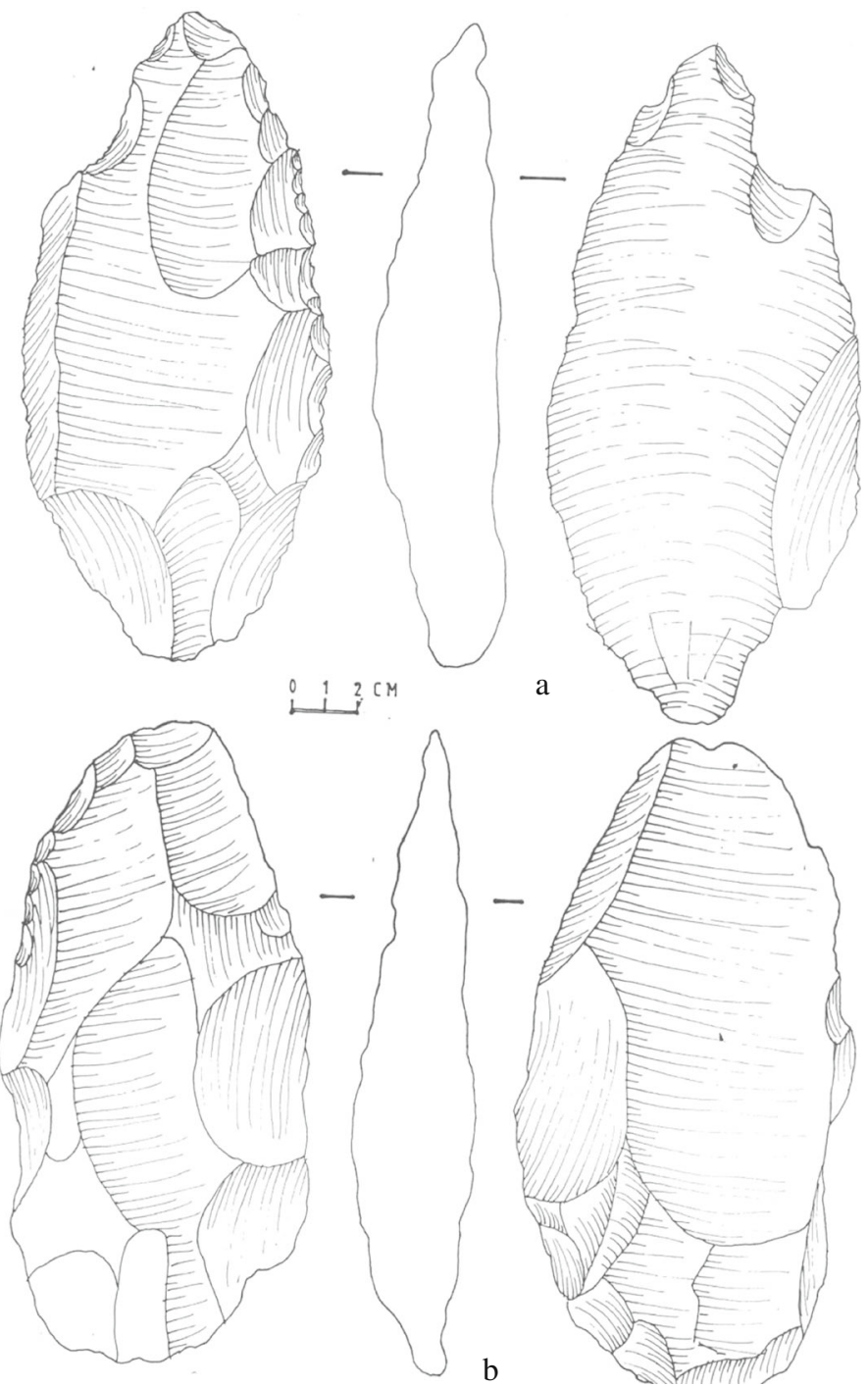

Fig. 8 Diminutive bifaces: a minimally worked and $\mathbf{b}$ fully bifacially worked from site F4

anatomically fully modern humans and archaic Homo sapiens are the discoveries of the LH18 and Ndutu skull from Laetoli and Ndutu, respectively, in southern Serengeti (Day et al. 1980; Mturi 1976; Rightmire 1983). Comparing the Mode 3 industries of Tanzania with those recovered from better dated sites in southern Africa, it can be argued that the hunting and gathering communities who made and used Mode 3 industries date to between 200,000 and 20,000 years ago. The dominating assemblage from East Natron has all the typological and technical attributes that would qualify it as MSA, although as remarked elsewhere, there is a possibility of the occurrence of MSA/ LSA, perhaps comparable to the Mumba industry (Mehlmann 1989), although the recognition of MSA/LSA is questioned by some scholars (Diez-Martín et al. 2009). 
Typological attributes for the MSA include implements normally associated with the MSA such as diminutive bifaces, bifacial points, large Levalloisian points, Levalloisian flakes and blades, discoidal cores and core axes. On the other hand, technological attributes include the Levalloisian discoidal flaking whereby the core is worked around the perimeter, and there is a relative increase in the production of blades compared to the succeeding LSA industries. The East Natron MSA assemblages are on the basis of the tool types, especially the proliferation of bifacially worked points and scrapers, most tentatively comparable to the Kisele industry, but affirmation is subject to more fieldwork in the area. As already remarked, the MSA in Tanzania is yet to be well documented, and hence, any little additional information about the MSA, such as this, should be appreciated (Masao 2008).
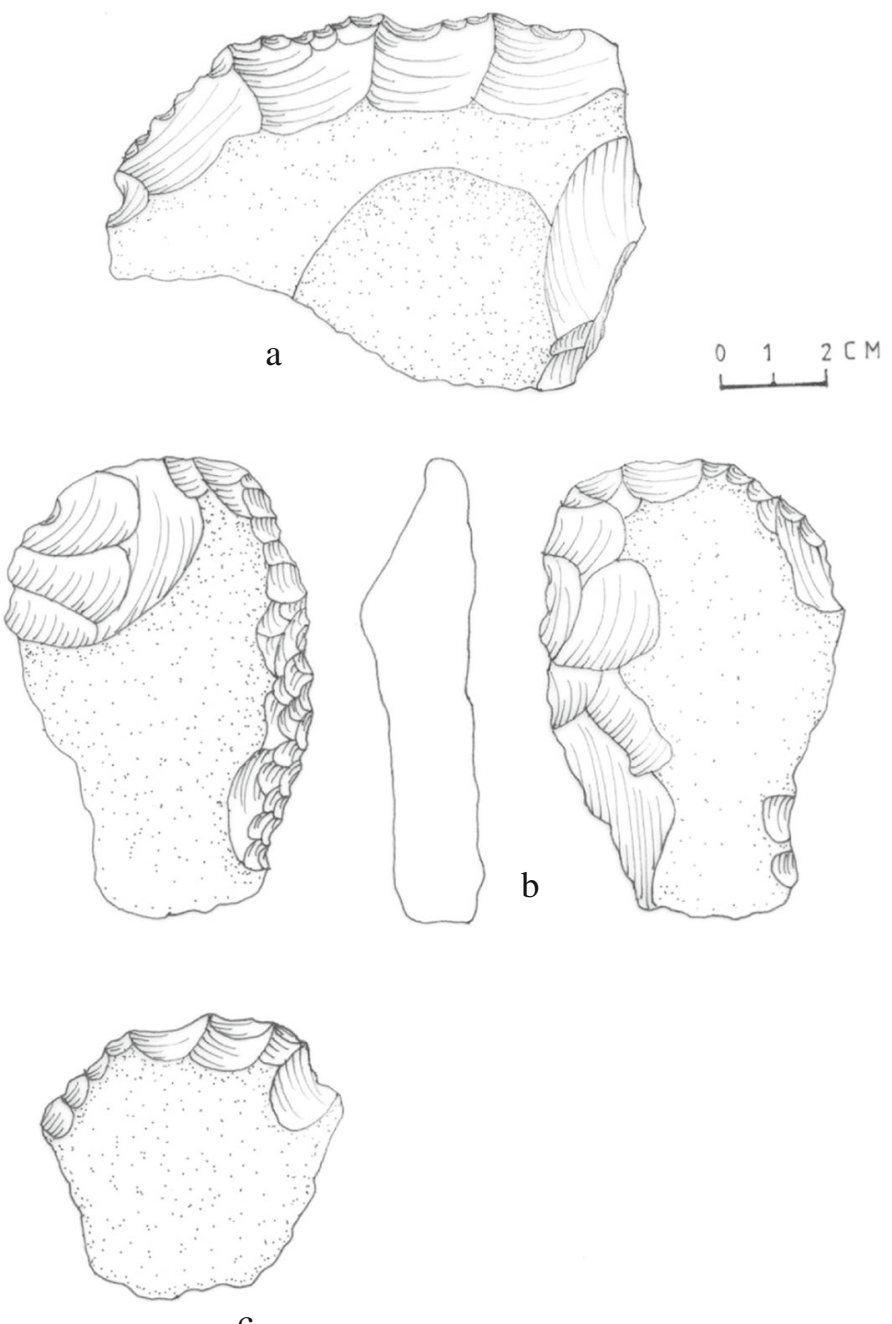

$\mathrm{c}$

Fig. 9 a Core axe (site F4), b End side scraper (site N10), and c End scraper (site T3) 
While the possibility that these artifacts that may have rolled down from higher ground can be entertained, careful examination for edge dulling, rolling, and/or abrasion proved that very few of the artifacts exhibited such modification (for a few illustrations of artifacts, see Figs. 6, 7, 8, and 9). This would suggest that either the artifacts had recently been exposed, or they may have been transported for a negligible distance.

Given the paucity of known, sealed, and dense MSA sites in Tanzania, the eastern part of the Lake Natron basin, especially the northeastern, seems to be an important and large archaeological landscape which needs to be studied in more detail. Studies focusing on MSA lithic technological attributes would be particularly suitable because there are so many artifact types. The bifaces are intriguing, for example, because they are few in number, and cannot yet be assigned to an industrial taxon. They may belong either to an industry earlier than typical MSA, in which case they would suggest the presence of a Njarasa-like industry, one recognized by Mehlmann (1989) from the Lake Eyasi Basin, or alternatively they may belong to an industry intermediate between MSA and Terminal Acheulean. Whatever the case, evaluation of the significance of the few bifaces found through the present fieldwork will proceed when more sealed sites in the area have been located and studied.

Acknowledgements This research was carried out as part of an Environmental and Social Impact Assessment (ESIA) of the then-proposed Soda Ash Mining Project, as required by the Tanzanian National Environmental Council, and the Antiquities Policy of the Ministry of Natural Resources and Tourism, Tanzania.

Open Access This article is distributed under the terms of the Creative Commons Attribution License which permits any use, distribution, and reproduction in any medium, provided the original author(s) and the source are credited.

\section{References}

Ambrose, S. H. (1998). Chronology of the Later Stone Age and food production in East Africa. Journal of Archaeological Science, 25, 377-392.

Anthony, B. (1978). The prospect industry - a definition. PhD dissertation, Harvard University.

Baker, B. H. (1958). Geology of the Magadi area. Kenya Geological Survey Report, 42, 81.

Baker, B. H. (1963). Geology of the area south of Magadi. Kenya Geological Survey Report, 61, 27.

Baker, B. H. (1986). Tectonics and volcanoes of the southern Kenya Rift Valley and its influence on rift sedimentation. In L. E. Frostick, R. W. Renaut, I. Reid, \& J. J. Tiercelin (Eds.), Sedimentation in the African rifts (pp. 45-58). Oxford: Blackwell Scientific Publications.

Bittner, K., Bushozi, P., \& Willoughby, P. (2007). The Middle and Later Stone Age of the Iringa region, southern Tanzania. An introduction. Nyame Akuma, 68, 62-73.

Bower, J. R. F., \& Mabulla, A. Z. P. (2008). Settling in: Evidence of terrestrial exclusion in the Later Middle Stone Age of northern Tanzania. Paper presented at SAfA in Frankfurt, September 8-11.

Bower, J. R. F., Gifford, D. P., \& Livingstone, D. (1985). Excavations at the Loyangalani Site, Serengeti National Park, Tanzania. National Geographic Society Research Reports, 20, 41-56.

Bushozi, P. G. M. (2003). Middle Stone Age occurrences and hominid behavior patterns in West Lake Natron region, northern Tanzania. Unpublished M.A. thesis, University of Dar es Salaam.

Bushozi, P. G. (2011). Lithic technology and human behavior during the Middle Stone Age in Tanzania. Unpublished Ph.D thesis, University of Alberta.

Camilli, E. L., \& Ebert, J. I. (1992). Artifact reuse and recycling in continuous surface distributions and implications for interpreting land use patterns. In J. Rossignol \& L. Wandsnider (Eds.), Space, time and archaeological landscapes (pp. 113-136). New York: Plenum Press.

Clark, J. D. (1970). The prehistory of Africa. London: Thames Hudson. 
Clark, J. D. (1975). Africa in prehistory: Peripheral or paramount? The Huxley Memorial Lecture for 1974. Man, 10, 175-198.

Clark, J. D. (1988). The Middle Stone Age of East Africa and the beginning of regional identity. Journal of World Prehistory, 2, 235-305.

Day, M. H., Leakey, M. D., \& Magori, C. (1980). A new hominid fossil skull (LH18) from the Ngaloba Beds, Laetoli, Northern Tanzania. Nature, 284, 55-56.

De la Torre, I., Mora, R., \& Martinez-Moreno, J. (2008). The early Acheulean in Peninj (Lake Natron, Tanzania). Journal of Anthropological Archaeology, 27, 244-264.

Diez-Martín, F. M., Domínguez-Rodrigo, M. L., Sánchez, P., Mabulla, A. Z. P. Tarriño, A., Barbra, R. Prendergast, M. E., \& de Luque, L. (2009). The Middle to Later Stone Age technological transition in East Africa. New data from Mumba Rockshelter Bed V (Tanzania) and their implications for the origin of modern human behavior. Journal of African Archaeology, 7(2), 147-173.

Dominguez-Rodrigo, M. L., Alcala, L., \& Luque, L. (Eds.). (2009a). Peninj: A research project on human origins (1995-2005). Oxford: Oxbow Books.

Dominguez-Rodrigo, M. L., Alcala, L., \& Luque, L. (2009b). Conclusions. In M. Dominguez-Rodrigo, L. Alcala, \& L. Luque (Eds.), Peninj: A research project on human origins (1995-2005) (pp. 257-258). Oxford: Oxbow Books.

Dominguez-Rodrigo, M., Lopez-Saez, J. A., Vicens, A., Alcala, L., Luque, L., \& Serralonga, J. (2001a). Fossil pollen from the Upper Humbu Formation Peninj, (Tanzania). Hominid adaptation to a dry open PlioPleistocene savanna environment. Journal of Human Evolution, 40, 151-157.

Dominguez-Rodrigo, M., Serralonga, J., Juan-Tresserras, J., Alcala, L., \& Luque, L. (2001b). Wood working activities by early humans: A plant residue analysis on Acheulian stone tools from Peninj (Tanzania). Journal of Human Evolution, 40, 289-299.

Dominguez-Rodrigo, M., de la Torre, I., Luque, L., Alcala, L., Mora, R., Serralonga, J., \& Medina, V. (2002). The ST site complex at Peninj West Natron, Tanzania. Implications for early hominid behavior models. Journal of Archaeological Science, 29, 639-665.

Foster, A. C., Ebinger, C., Mbede, E., \& Rex, D. (1997). Tectonic development of the northern Tanzania sector of the East African rift system. Journal of the Geological Society London, 154, 689-700.

Gliganic, L. A., Jacobs, Z., Roberts, R. G., Dominguez-Rodrigo, M., \& Mabulla, A. Z. (2012). New ages for Middle and Later Stone Age deposits at Mumba rock shelter, Tanzania. Optically stimulated luminescence dating of quartz and feldspar grains. Journal of Human Evolution, 62, 533-547.

Harvey, G. M. (1993). Middle Stone Age occurrences in southwestern Tanzania. An assessment of technology and adaptation in Songwe River region. $\mathrm{PhD}$ dissertation, University of Alberta, Edmonton.

Hay, R. L. (1968) Chert and its sodium-silicate precursors in sodium-carbonate lakes in East Africa. Contributions to Mineralogy and Petrology 17, 255-74.

Idara ya Mambo ya Kale (Antiquities Department). (2008). Sera ya Malikale, Wizara ya Mali Asili na Utalii (Antiquities Policy, Ministry of Natural Resources and Tourism). Dar es Salaam: Government of the United Republic of Tanzania, Afrikan Image Publications Ltd.

Isaac, G. L. (1967). The stratigraphy of the Peninj Group. Early Middle Pleistocene formations west of Lake Natron, Tanzania. In W. W. Bishop \& J. D. Clark (Eds.), Background to evolution in Africa (pp. 229257). Chicago: University of Chicago Press.

Isaac, G. L., \& Curtis, G. H. (1974). Age of early Acheulean industries from the Peninj Group, Tanzania. Nature, 249, 624-627.

Kusimba, C. M., \& Kusimba, S. B. (2003). East African archaeology: foragers, potters, smiths, and traders. Philadelphia: University of Pennsylvania Museum of Archaeology and Anthropology.

Leakey, M. D. (1971) Olduvai Gorge Vol 3. Excavations in Beds I and II, 1960-1963. London: Cambridge at the University Press.

Leakey, M. D., Hay, R. L., Thurber, D. L., Protsch, R., \& Berger, R. (1972). Stratigraphy, archaeology, and age of the Ndutu and Nasiusiu Beds, Olduvai Gorge, Tanzania. World Archaeology, 3(3), 328-341.

Luque, L., Alcala, L., \& Dominguez-Rodrigo, M. (2009). The Peninj Group: Tectonics, volcanism and sedimentary palaeoenvironments during the Lower Pleistocene in the Lake Natron Basin (Tanzania). In M. Dominguez-Rodrigo, L. Alcala, \& L. Luque (Eds.), Peninj: A research project on human origins (1995-2005) (pp. 15-48). Oxford: Oxbow Books.

Manega, P. C. (1993). Geochronology, geochemistry and isotopic study of the Plio-Pleistocene hominid sites and the Ngorongor volcanic highlands in northern Tanzania. Unpublished $\mathrm{PhD}$ dissertation, University of Chicago.

Masao, F. T. (2008). A Middle Stone Age/Later Stone Age industry from Buzwagi Kahama Sinyanga region, Tanzania. Results of cultural impact assessment. Nyame Akuma, 70, 30-48.

Mabulla, A. Z. P. (1996). Middle and Later Stone Age land-use and lithic technology in the Eyasi Basin, Tanzania. PhD dissertation, University of Florida. 
McBrearty, S. (1981). Songhor: A Middle Stone Age site in western Kenya. Quaternaria, 23, 171-190.

McBrearty, S. (1988). The Sangoan-Lupemban and MSA sequence at the Muguruk site. Western Kenya. World Archaeology, 19(3), 388-420.

McBrearty, S. (1991). Recent research in Western Kenya and its implication for the status of the Sangoan industry. In J. D. Clark (Ed.), Cultural beginnings (pp. 159-176). Bonn: Dr. Rudolf Habelt GMBH.

McBrearty, S. (1992). Sangoan technology and habitat at Simbi. Nyame Akuma, 38, 3440.

McBrearty, S. (1993). Reconstructing the environmental conditions surrounding the appearance of modern humans in East Africa. In R. Jamieson, S. Abonyi, \& N. Mirau (Eds.), Culture and environment: A fragile coexistence (pp. 145-154). Calgary: Chacmool Archaeological Association.

McBrearty, S. (1999). The archaeology of the Kapthurin formation. In P. Andrews \& P. Banham (Eds.), Late Cenozoic environments and hominid evolution (pp. 143-156). London: Geological Society.

McBrearty, S., Waane, S. A. C., \& Wynn, T. G. (1982). Mbeya region archaeological survey. Tanzania Notes and Records, 88(89), 15-32.

McBrearty, S., Wynn, T. G., \& Waane, S. A. C. (1984). Archaeological survey in Mbeya region, southern Tanzania. Azania, 19, 128-132.

Mehlmann, M. J. (1979). Mumba- Hohle revisited: The relevance of a forgotten excavation to some current issues in East African prehistory. World Archaeology, 11, 80-94.

Mehlmann, M. J. (1989). Later Quaternary archaeological sequence in northern Tanzania. PhD dissertation, University of Illinois-Urbana.

Merrick, H.V. (1975). Change in Late Pleistocene lithic technology in eastern Africa. PhD dissertation, University of California, Berkeley.

Mora, R., Dominguez-Rodrigo, M., de la Torre, I., Luque, L., \& Alcala, L. (2001). The archaeology of the Peninj "ST Complex" (Lake Natron Tanznaia). In J. M. Moreno, R. M. Torcal, \& I. de la Torre (Eds.), Oldowan: Rather more than smashing stones. First hominid technology workshop (pp. 78-116). Barcelona: Centre d'Estudis del Patrimoni Arqueologic de la Prehistoria Universitat Autonoma de Bacelona.

Mturi, A. A. (1976). New hominid from Lake Ndutu, Tanzania. Nature, 262, 484- 485.

Rafalski, S., P.Schroter \& E. Wagner,. 1978: Die archäologischen und anthropologischen Ergebnisse der KohlLarsen -Expeditionen in Nord-Tanzania 1933-1939, Herausgegeben von H. Muller-Beck. Band 2. Die Funde am Eyasi -Nordostufer. Tubinger Monographien zur Urgeschichte. Verlag Archaeologica Venatoria, Institut fur Urgeschichte der Universitat Tubingen.

Rightmire, A. F. (1983). The Lake Ndutu cranium and early Homo sapiens in Africa. American Journal of Physical Anthropology, 61, 247-254.

Schick, K., \& Toth, N. (2006). An overview of the Oldowan industrial complex: The sites and the nature of their evidence. In N. Toth \& K. Schick (Eds.), The Oldowan: Case studies into the earliest Stone Age (pp. 3-42). Bloomington: Stone Age Institute Press.

Sherrod, D. R., Magigita, M. M., \& Kwela, S. (2013). Geological map of Oldonyo Lengai (Oldoinyo Lengai) volcano and surroundings, Arusha region, United Republic of Tanzania: U.S. Geological Survey.

Skinner, A. R., Hay, R. L., Masao, F. T., \& Blackwell, B. A. B. (2003). Dating the Nasiusiu Beds, Olduvai Gorge by electron spin resonance. Quaternary Science Review, 22(10-13), 1361-1366.

Thouveny, N. \& Taieb, M. (1987). Étude paléomagnétique des formations du Plio-Pléistocène de la région de la Peninj (Ouest du Lac Natron, Tanzanie). Limites de l'interprétation magnétostratigraphique. Bulletin Sciences Géologiques 1-2, 57-70.

Toth, N., \& Schick, K. (Eds.). (2006). The Oldowan: Case studies into the earliest Stone Age. Bloomington: Stone Age Institute Press.

Vanetti, I. (2009/2010). Evolutionary process in an environmentally challenging site: The soda Lake Natron, Tanzania. PhD dissertation, Universita Degli Studi Del' Isubria.

Willoughby, P. R. (1993). The Middle Stone Age in East Africa and modern human origins. The African Archaeological Review, 11, 3-20.

Willoughby, P. R. (2007). The evolution of modern humans in Africa: A comprehensive guide. Lanham: Altamira Press. 